\title{
Jeotgalibacillus soli sp. nov., a Gram-stain-positive bacterium isolated from soil
}

\author{
Sofia Cunha, Igor Tiago, Gabriel Paiva, Fernanda Nobre, \\ Milton S. da Costa and António Veríssimo
}

Correspondence

António Veríssimo

averiss@ci.uc.pt
Department of Life Sciences, Apartado 3046, University of Coimbra, 3001-401 Coimbra, Portugal, and Center for Neuroscience and Cell Biology, University of Coimbra, 3004-517 Coimbra, Portugal
A Gram-staining-positive, motile, rod-shaped, spore-forming bacterium, designated $\mathrm{P9}^{\top}$, was isolated from soil in Portugal. This organism was aerobic and catalase- and oxidase-positive. It had an optimum growth temperature of about $35{ }^{\circ} \mathrm{C}$ and an optimum growth $\mathrm{pH}$ of about 8.08.5 , and grew in medium with $0-9 \%(\mathrm{w} / \mathrm{v}) \mathrm{NaCl}$. The cell-wall peptidoglycan was of the A1 $\alpha$ type, with L-lysine as the diagnostic diamino acid. The major respiratory quinone was menaquinone 7 (MK-7) and the major fatty acids were anteiso- $\mathrm{C}_{15: 0}(45.4 \%)$, iso- $\mathrm{C}_{15: 0}(22.0 \%)$ and anteiso$\mathrm{C}_{17: 0}(11.2 \%)$. The genomic DNA G+C content was about $39.4 \mathrm{~mol} \%$. Phylogenetic analysis based on 16S rRNA gene sequences indicated that strain $\mathrm{P9}^{\top}$ was most closely related to Jeotgalibacillus campisalis DSM $18983^{\top}(96.8 \%)$ and Jeotgalibacillus marinus DSM $1297^{\top}$ $(96.5 \%)$. These two recognized species formed a coherent cluster with strain $\mathrm{P}^{\top}$ that was supported by a bootstrap value of $99 \%$. On the basis of the phylogenetic analysis and physiological and biochemical characteristics, strain $\mathrm{Pg}^{\top}\left(=\mathrm{DSM} 23228^{\top}=\mathrm{LMG}_{\left.25523^{\top}\right)}\right.$ represents a novel species of the genus Jeotgalibacillus, for which the name Jeotgalibacillus soli sp. nov. is proposed.
The genus Jeotgalibacillus was initially proposed to accommodate organisms that had cell-wall peptidoglycan based on the diamino acid L-lysine, MK-7 and MK-8 as the predominant menaquinones, and anteiso- $\mathrm{C}_{15: 0}$ as the major fatty acid (Yoon et al., 2001). In a recent taxonomic reevaluation, it was proposed that species previously assigned to the genus Marinibacillus, which also have L-lysine-based peptidoglycan, MK-7 and MK-8 as their predominant menaquinones and anteiso- $\mathrm{C}_{15: 0}$ as their major fatty acid, should be moved to the genus Jeotgalibacillus (Yoon et al., 2010). At the time of writing, the genus Jeotgalibacillus comprises four recognized species: Jeotgalibacillus salarius, J. alimentarius, J. campisalis and J. marinus. Preliminary phylogenetic analyses based on 16S rRNA gene sequences indicated that a bacterium, designated strain $\mathrm{P}^{\mathrm{T}}$, that was isolated from soil in Portugal was closely related to these recognized species in the genus Jeotgalibacillus. In this study, the morphological, physiological, chemotaxonomic and phylogenetic characteristics of strain $\mathrm{P}^{\mathrm{T}}$ were investigated in detail.

Strain $\mathrm{P}^{\mathrm{T}}$ was isolated on solid ABM2 medium (Tiago et al., 2004) from a sample of alkaline sandy soil (with a $\mathrm{pH}$ of

The GenBank/EMBL/DDBJ accession number for the 16S rRNA gene sequence of strain $\mathrm{Pg}^{\top}$ is FR693626.

A supplementary figure and a table are available with the online version of this paper. about 9) collected in southern Portugal. This medium contained, per litre: $5 \mathrm{~g}$ yeast extract (Difco), $5 \mathrm{~g}$ tryptone (Difco), $1 \mathrm{~g} \alpha$-ketoglutaric acid monopotassium salt, $15 \mathrm{~g}$ agar (Difco), $50 \mathrm{mmol} \mathrm{N}$-cyclohexyl-2-hydroxyl-3-aminopropanesulfonic acid (CAPSO; $\mathrm{pH} 9.0$ ), $100 \mathrm{ml} 10 \times$ macronutrient solution and $10 \mathrm{ml} 100 \times$ micronutrient solution. The $10 \times$ macronutrient solution contained $1 \mathrm{~g}$ nitrilotriacetic acid, $0.6 \mathrm{~g} \mathrm{CaSO}_{4} .2 \mathrm{H}_{2} \mathrm{O}, 1 \mathrm{~g} \mathrm{MgSO}_{4} \cdot 7 \mathrm{H}_{2} \mathrm{O}, 0.8 \mathrm{~g}$ $\mathrm{NaCl}, 1.0 \mathrm{~g} \mathrm{KNO}_{3}, 6.9 \mathrm{~g} \mathrm{NaNO}_{3}$ and $1.1 \mathrm{~g} \mathrm{NaHPO}_{4} \mathrm{l}^{-1}$, while the $100 \times$ micronutrient solution contained $0.2 \mathrm{~g}$ $\mathrm{MnSO}_{4} . \mathrm{H}_{2} \mathrm{O}, 0.05 \mathrm{~g} \mathrm{ZnSO}_{4} .7 \mathrm{H}_{2} \mathrm{O}, 0.05 \mathrm{~g} \mathrm{H}_{3} \mathrm{BO}_{3}, 2.5 \mathrm{mg}$ $\mathrm{CuSO}_{4} \cdot 5 \mathrm{H}_{2} \mathrm{O}, \quad 2.5 \mathrm{mg} \quad \mathrm{Na}_{2} \mathrm{MoO}_{4} \cdot 2 \mathrm{H}_{2} \mathrm{O}$ and $4.6 \mathrm{mg}$ $\mathrm{CoCl}_{2} \cdot 6 \mathrm{H}_{2} \mathrm{O} \mathrm{l}^{-1}$. The CAPSO buffer and concentrated macro- and micro-nutrient solutions were autoclaved separately from the other components, and the components were only mixed after they had cooled to $50{ }^{\circ} \mathrm{C}$. The soil sample was processed as described by Steele et al. (1990). The bacterial isolates were purified by subculture on the same medium and maintained at $-70{ }^{\circ} \mathrm{C}$ in liquid $\mathrm{ABM} 2$ medium ( $\mathrm{pH}$ 9.0; Tiago et al., 2004) with $15 \%$ (v/v) glycerol. In the characterization of strain $\mathrm{P}^{\mathrm{T}}$, J. campisalis DSM $18983^{\mathrm{T}}$ and J. marinus DSM $1297^{\mathrm{T}}$ were used for reference.

Unless stated otherwise, all morphological, biochemical and tolerance tests were performed using cultures that were grown, for $24 \mathrm{~h}$ at $30{ }^{\circ} \mathrm{C}$, in liquid ABM2 buffered at $\mathrm{pH} 8.0$ with $50 \mathrm{mM}$ TAPS and containing $1 \%(\mathrm{w} / \mathrm{v}) \mathrm{NaCl}$. Cell morphology, dimensions and motility were examined by 
phase-contrast light microscopy. Gram staining, flagellum number and location, and cytochrome oxidase and catalase activities were determined as described by Smibert \& Krieg (1981). Endospore formation was assessed on two modifications of solid ABM2 medium. Although both modifications to the medium contained $5 \mathrm{mg} \mathrm{MnSO}_{4} \mathrm{l}^{-1}$, one had the nutrient content reduced to $50 \%$ of that in the standard medium and the other had such content reduced to $10 \%$ of the standard value (Logan et al., 2009). Cultures of strain $\mathrm{P}^{\mathrm{T}}$ and the type strains of J. campisalis and J. marinus used for reference were grown on each of these modified media at $30{ }^{\circ} \mathrm{C}$ for up to 7 days. The cultures were then checked for endospores as described by Smibert \& Krieg (1981). Growth of strain $\mathrm{P}^{\mathrm{T}}$ was followed in liquid $\mathrm{ABM} 2$ at $10-50{ }^{\circ} \mathrm{C}$ (with intervals of $5{ }^{\circ} \mathrm{C}$ ) and at $30{ }^{\circ} \mathrm{C}$ in the same medium buffered to give $\mathrm{pH}$ values between 5.5 and 10.5 (with intervals of 0.5 $\mathrm{pH}$ units). The $\mathrm{pH}$ range was created using MES, ACES, TAPS, CAPSO or CAPS, as appropriate, each at $50 \mathrm{mM}$. Salt tolerance was explored in liquid ABM2 with $0-15 \%(w / v)$ $\mathrm{NaCl}$ (with intervals of $1 \%$ ). Acid production and enzyme activities were investigated using the API $50 \mathrm{CHB} / \mathrm{E}$ system and API ZYM test strips (bioMérieux), respectively, as recommended by the manufacturer. Nitrate reduction, indole production, presence of $\beta$-galactosidase and urease, and hydrolysis of gelatin and aesculin were determined using the API 20NE system (bioMérieux), as recommended by the manufacturer. Additionally, the hydrolysis of arginine, elastin, arbutin, gelatin, casein, aesculin, starch and hippurate, and the presence of urease, xylanase and DNase were also assessed, on solid ABM2 for up to 6 days, as described by Hudson et al. (1986) and Smibert \& Krieg (1981). Results were recorded after 24,48 and $72 \mathrm{~h}$ of incubation at $30{ }^{\circ} \mathrm{C}$.

The cultures for polar lipid analysis were incubated, at $30{ }^{\circ} \mathrm{C}$ for 3 days, on solid ABM2 medium buffered at $\mathrm{pH} 8.0$ and containing $1 \% \mathrm{NaCl}$. Harvesting of the cultures, extraction of the lipids and two-dimensional TLC, as well as the analysis of respiratory quinones, were performed as described by da Costa et al. (2006). Solid ABM2 medium buffered at $\mathrm{pH} 8.0$ and containing $1 \%$ $\mathrm{NaCl}$ was also used to grow the cells of strain $\mathrm{P9}^{\mathrm{T}}, \mathrm{J}$. campisalis DSM $18983^{\mathrm{T}}$ and J. marinus DSM $1297^{\mathrm{T}}$ used

Table 1. Differential phenotypic characteristics of strain $P 9^{\top}$ and J. marinus DSM $1297^{\top}$ and J. campisalis DSM $18983^{\top}$

Taxa: 1, strain $\mathrm{P9}^{\mathrm{T}}$; 2, J. marinus DSM $1297^{\mathrm{T}}$; 3, J. campisalis DSM $18983^{\mathrm{T}}$. All results from this study. +, Positive; -, negative; w, weakly positive.

\begin{tabular}{|c|c|c|c|}
\hline Characteristic & 1 & 2 & 3 \\
\hline Catalase & + & - & - \\
\hline Nitrate reduction & - & - & + \\
\hline \multicolumn{4}{|l|}{ Growth with/at: } \\
\hline $0 \% \mathrm{NaCl}$ & + & - & - \\
\hline \multicolumn{4}{|l|}{ Hydrolysis of: } \\
\hline Aesculin & - & + & + \\
\hline Casein & - & + & + \\
\hline Gelatin & - & + & - \\
\hline Urea & + & - & - \\
\hline D-Xylose & - & + & - \\
\hline D-Mannitol & + & - & + \\
\hline Raffinose & + & - & - \\
\hline D-Mannose & - & + & - \\
\hline \multicolumn{4}{|c|}{ Enzyme activity (API ZYM) } \\
\hline Esterase (C4) & $\mathrm{w}$ & - & - \\
\hline Esterase lipase (C8) & $\mathrm{w}$ & - & - \\
\hline Valine arylamidase & $\mathrm{w}$ & - & - \\
\hline$\beta$-Galactosidase & - & - & + \\
\hline$\alpha$-Glucosidase & + & - & $\mathrm{W}$ \\
\hline Major fatty acids & $\begin{array}{l}\text { anteiso- }_{15: 0}(45.4 \%) \\
\text { iso- } \mathrm{C}_{15: 0}(22.0 \%) \text { and } \\
\text { anteiso- } \mathrm{C}_{17: 0}(11.2 \%)\end{array}$ & $\begin{array}{l}\text { anteiso- } \mathrm{C}_{15: 0}(40.6 \%) \text {; iso- } \mathrm{C}_{15: 0} \\
\begin{aligned} &(22.1 \%) \text { and anteiso- } \mathrm{C}_{17: 0} \\
&(13.1 \%)\end{aligned}\end{array}$ & $\begin{array}{c}\text { anteiso- } \mathrm{C}_{15: 0}(46.4 \%) ; \text { anteiso- } \mathrm{C}_{17: 0} \\
(11.5 \%) \text { and } \mathrm{C}_{16: 1} \omega 7 c \text { alcohol } \\
(10.2 \%)\end{array}$ \\
\hline
\end{tabular}


for the fatty acid analyses, the cultures being incubated in a water bath at $30{ }^{\circ} \mathrm{C}$ for 3 days. Fatty acid methyl esters (FAME) were obtained from fresh wet biomass by saponification, methylation and extraction, and the fatty acids then identified and quantified with standard MIS Library Generation software (Microbial ID Inc.), as described by the manufacturer. Peptidoglycan analysis was performed, as described previously (Schleifer, 1985), by the Deutsche Sammlung von Mikroorganismen und Zellkulturen (DSMZ) in Braunschweig, Germany.

The genomic DNA G+C content of strain $\mathrm{P9}^{\mathrm{T}}$ was determined by HPLC (Mesbah et al., 1989) four times, with the mean value and standard deviation calculated. The $16 \mathrm{~S}$ rRNA gene of the novel strain was sequenced (Rainey et al., 1996) and phylogenetic analyses were performed using the ARB software package (Ludwig et al., 2004). Phylogenetic trees were constructed using the neighbour-joining (Saitou $\&$ Nei, 1987) and maximum-parsimony (Felsenstein, 1983) algorithms included in the ARB software package. The topology of the neighbour-joining tree, which was based on evolutionary distances calculated using the Jukes-Cantor correction (Jukes \& Cantor, 1969), was evaluated by performing bootstrap analysis (Felsenstein, 1985) with 1000 resamplings of the dataset.

Overall, 27 bacterial strains were isolated from the sample of alkaline sandy soil but only one strain, designated $\mathrm{P}^{\mathrm{T}}$, appeared to be a novel species in the genus Jeotgalibacillus. The other 26 isolates were phylogenetically related to the genera Arthrobacter, Planococcus, Kocuria, Dietzia or Microbacterium. Strain $\mathrm{P}^{\mathrm{T}}$ formed Gram-staining-positive rod-shaped cells that were motile by means of a polar or subpolar flagellum. This strain produced endospores when grown in medium with low nutrient levels that had been supplemented with $5 \mathrm{mg} \mathrm{MnSO}_{4} \mathrm{l}^{-1}$. The organism was aerobic and catalase- and oxidase-positive. A more exhaustive description of the physiological characteristics of strain $\mathrm{P}^{\mathrm{T}}$ is given in Table 1, Supplementary Table S1 (available in IJSEM Online) and in the species description. In the analysis of the polar lipids of strain $\mathrm{P9}^{\mathrm{T}}$, four aminophospholipids were visualized on TLC, as also seen with the type strains of J. campisalis and J. marinus (Supplementary Fig. S1). Strain $\mathrm{P} 9^{\mathrm{T}}$ possessed a cell-wall peptidoglycan structure of type $\mathrm{A} 1 \alpha$ (L-lysine). The major respiratory lipoquinone found in strain $\mathrm{P}^{\mathrm{T}}$ was menaquinone 7 (MK-7) and the major fatty acids were anteiso- $\mathrm{C}_{15: 0}(45.4 \%)$, iso- $\mathrm{C}_{15: 0}(22.0 \%)$ and anteiso- $\mathrm{C}_{17: 0}(11.2 \%)$ (Table 2).

The mean ( \pm standard deviation) genomic DNA G $+\mathrm{C}$ content of strain $\mathrm{P}^{\mathrm{T}}$ was $39.4 \pm 0.8 \mathrm{~mol} \%$. A partial sequence from the $16 \mathrm{~S}$ rRNA gene of strain $\mathrm{P}^{\mathrm{T}}$, comprising $1525 \mathrm{nt}$, was determined. Comparison of this sequence with the corresponding sequences of representatives of the main lines of descent within the domain Bacteria indicated that strain $\mathrm{P}^{\mathrm{T}}$ was a member of the family Bacillaceae (Fig. 1). Strain $\mathrm{P}^{\mathrm{T}}$ formed a coherent cluster, with a bootstrap resampling value of $99 \%$, with the type strains of two species of the genus Jeotgalibacillus: J. campisalis DSM $18983^{\mathrm{T}}$
Table 2. Cellular fatty acid profiles of strain $\mathrm{Pg}^{\top}$, J. marinus DSM $1297^{\top}$ and J. campisalis DSM $18983^{\top}$

Taxa: 1, strain $\mathrm{P}^{\mathrm{T}}$; 2, J. marinus DSM $1297^{\mathrm{T}}$; 3, J. campisalis DSM $18983^{\mathrm{T}}$. All cultures were grown in $\mathrm{ABM} 2$ at $\mathrm{pH} 8$ with $1 \% \mathrm{NaCl}$ and incubated at $30{ }^{\circ} \mathrm{C}$ for 3 days before cells were harvested for the preparation of fatty acid methyl esters. All results from this study. Values are percentages of total fatty acids and are presented as the mean \pm standard deviation of four analyses. - , Not detected; tr, trace $(<0.5 \%)$.

\begin{tabular}{|c|c|c|c|}
\hline Fatty acid & 1 & 2 & 3 \\
\hline \multicolumn{4}{|l|}{ Straight-chain } \\
\hline $\mathrm{C}_{14: 0}$ & $0.8 \pm 0.1$ & $0.6 \pm 0.1$ & $0.9 \pm 0.1$ \\
\hline $\mathrm{C}_{15: 0}$ & $1.1 \pm 0.1$ & $0.9 \pm 0.1$ & $1.6 \pm 0.1$ \\
\hline$C_{16: 0}$ & $2.3 \pm 0.4$ & $2.1 \pm 0.4$ & $1.3 \pm 0.3$ \\
\hline \multicolumn{4}{|l|}{ Branched } \\
\hline iso- $\mathrm{C}_{14: 0}$ & $1.6 \pm 0.4$ & $5.1 \pm 1.6$ & $8.2 \pm 2.9$ \\
\hline iso- $\mathrm{C}_{15: 0}$ & $22.0 \pm 0.3$ & $22.1 \pm 1.3$ & $6.8 \pm 1.2$ \\
\hline anteiso- $\mathrm{C}_{15: 0}$ & $45.4 \pm 0.9$ & $40.6 \pm 0.1$ & $46.4 \pm 1.5$ \\
\hline iso- $\mathrm{C}_{16: 0}$ & $2.5 \pm 0.3$ & $9.4 \pm 0.5$ & $6.1 \pm 0.7$ \\
\hline iso- $\mathrm{C}_{17: 0}$ & $5.7 \pm 0.8$ & $4.1 \pm 0.4$ & $0.6 \pm 0.7$ \\
\hline anteiso- $\mathrm{C}_{17: 0}$ & $11.2 \pm 0.9$ & $12.95 \pm 0.6$ & $11.5 \pm 2.5$ \\
\hline iso- $\mathrm{C}_{17: 1} \omega 10 c$ & $0.5 \pm 0.3$ & - & - \\
\hline \multicolumn{4}{|l|}{ Unsaturated } \\
\hline $\mathrm{C}_{16: 1} \omega 7 c$ alcohol & $1.8 \pm 0.3$ & $0.8 \pm 0.4$ & $10.2 \pm 2.9$ \\
\hline $\mathrm{C}_{16: 1} \omega 11 c$ & $2.5 \pm 0.2$ & $\operatorname{tr}$ & $2.9 \pm 0.1$ \\
\hline iso- $\mathrm{C}_{17: 1} \mathrm{I} /$ anteiso $\mathrm{B}$ & $1.1 \pm 0.8$ & $0.6 \pm 0.4$ & $3.4 \pm 0.7$ \\
\hline
\end{tabular}

(96.8\% sequence similarity) and J. marinus DSM $1297^{\mathrm{T}}$ (96.5\%). These two species were the recognized organisms that appeared to be most closely related to strain $\mathrm{P9}^{\mathrm{T}}$, each showing $>96.4 \% 16 \mathrm{~S}$ rRNA gene sequence similarity with the novel organism. Strain $\mathrm{P}^{\mathrm{T}}$ shared lower $16 \mathrm{~S}$ rRNA gene sequence similarity values (about 94.2\%) with the type strains of J. alimentarius and J. salarius.

Several characteristics of strain $\mathrm{P}^{\mathrm{T}}$, such as its type-A1 $\alpha$ peptidoglycan structure, lipid composition, and fatty acid content (with large amounts of branched fatty acids and a predominance of anteiso- $\mathrm{C}_{15: 0}$, iso- $\mathrm{C}_{15: 0}$ and anteiso$\mathrm{C}_{17: 0}$ ) were typical of the genus Jeotgalibacillus, reinforcing the phylogenetic assignment of the novel strain to this genus. Nevertheless, differences in the proportions of some fatty acids, particularly in the levels of iso- $\mathrm{C}_{14: 0}$, iso- $\mathrm{C}_{15: 0}$, iso- $\mathrm{C}_{16: 0}$, iso- $\mathrm{C}_{17: 0}$ and $\mathrm{C}_{16: 1} \omega 7 \mathrm{c}$ alcohol, could be found between the novel isolate and both J. campisalis DSM $18983^{\mathrm{T}}$ and J. marinus DSM $1297^{\mathrm{T}}$.

Strain $\mathrm{P}^{\mathrm{T}}$ could be differentiated from J. campisalis DSM $18983^{\mathrm{T}}$ and J. marinus DSM $1297^{\mathrm{T}}$ by several phenotypic characteristics, including its growth temperature range, growth in medium with added $\mathrm{NaCl}$, the pattern of acid production from carbohydrates and its enzyme activities. Based on the differential characteristics and on the phylogenetic evidence, strain $\mathrm{P}^{\mathrm{T}}$ is proposed to represent a novel species, for which the name Jeotgalibacillus soli sp. nov. is proposed. 


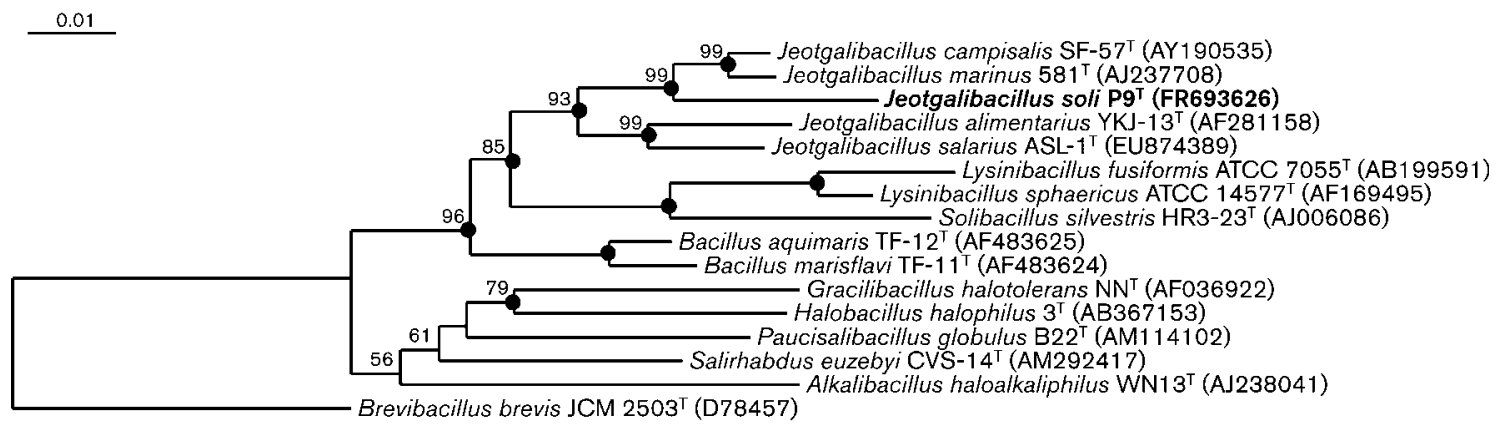

Fig. 1. Neighbour-joining tree based on a comparison of the $16 \mathrm{~S}$ rRNA gene sequences of strain $P 9^{\top}$ and its closest, recognized phylogenetic relatives. Bootstrap values (\%) for 1000 replicates are given at branch points. Filled circles indicate that the corresponding nodes were also recovered in the trees generated using the maximum-parsimony and maximumlikelihood algorithms. Bar, 0.01 substitution per nucleotide position.

\section{Description of Jeotgalibacillus soli sp. nov.}

Jeotgalibacillus soli (so'li. L. gen. neut. n. soli of or from soil).

Forms rod-shaped $(0.8 \mu \mathrm{m} \times 1.5-4 \mu \mathrm{m})$ cells that are Gramstaining-positive. Cells are convex, without pigmentation, motile by one polar or subpolar flagellum. Endospores, which are central or paracentral, form in diluted growth media supplemented with $5 \mathrm{mg} \mathrm{MnSO} \mathrm{I}^{-1}$. The organism is strictly aerobic and oxidase- and catalase-positive. The optimum growth temperature is between 30 and $37^{\circ} \mathrm{C}$, but growth also occurs at 15 and $40{ }^{\circ} \mathrm{C}$. The optimum $\mathrm{pH}$ is between 8.0 and 8.5, but growth also occurs at pH 5.5 and $\mathrm{pH}$ 10.5. Optimum growth occurs in medium with $0-1 \%$ $\mathrm{NaCl}(\mathrm{w} / \mathrm{v})$, although growth is still observed in medium with $9 \% \mathrm{NaCl}$. The cell-wall peptidoglycan is of the $\mathrm{A} 1 \alpha$ type, with L-lysine. The main respiratory menaquinone is MK-7. The major fatty acids are anteiso- $\mathrm{C}_{15: 0}$, iso- $\mathrm{C}_{15: 0}$ and anteiso- $\mathrm{C}_{17: 0}$. Nitrate is not reduced. Starch and urea are hydrolysed, but gelatin, aesculin, casein and Tween 20, Tween 40, Tween 60 and Tween 80 are not hydrolysed. DNase and urease are produced. Xylanase and $\beta$-galactosidase are not detected. In API $50 \mathrm{CHB} / \mathrm{E}$ tests, acid is produced from glycerol, D-ribose, D-glucose, D-fructose, Dmannitol, $\mathrm{N}$-acetylglucosamine, maltose, sucrose, trehalose, raffinose, starch, glycogen and inulin, but not from melibiose, melezitose, cellobiose, D-xylose, L-xylose, Dmannose, L-rhamnose, D-arabitol, L-arabitol, erythritol, Dgalactose, $\mathrm{D}$-adonitol, methyl $\beta$-D-xylopyranoside, $\mathrm{D}$-arabinose, L-arabinose, L-sorbose, sorbitol, inositol, D-sorbitol, methyl $\alpha$-D-mannopyranoside, methyl $\alpha$-D-glucopyranoside, amygdalin, arbutin, aesculin, salicin, lactose, xylitol, gentiobiose, turanose, L-lyxose, D-tagatose, D-fucose, L-fucose, potassium gluconate, potassium 2-ketogluconate or potassium 5-ketogluconate.

The type strain, $\mathrm{P9}^{\mathrm{T}}\left(=\mathrm{DSM} 23228^{\mathrm{T}}=\mathrm{LMG} 25523^{\mathrm{T}}\right)$, was isolated from soil in Portugal. The genomic DNA G $+\mathrm{C}$ content of the type strain is about $39.4 \mathrm{~mol} \%$ (HPLC method).

\section{Acknowledgements}

We are indebted to Peter Schumann (DSMZ) for the peptidoglycan analysis. This research was funded in part by the Fundação para a Ciência e a Tecnologia (FCT)/Fundo Europeu de Desenvolvimento Regional (FEDER) project POCI/BIA-BDE/60704/2004. Sofia Cunha acknowledges a PhD scholarship from the FCT (SFRH/BD/46212/ 2008).

\section{References}

da Costa, M. S., Nobre, M. F. \& Wait, R. (2006). Analysis of lipids from extremophilic bacteria. Methods Microbiol 35, 127-159.

Felsenstein, J. (1983). Parsimony in systematics: biological and statistical issues. Annu Rev Ecol Syst 14, 313-333.

Felsenstein, J. (1985). Confidence limits on phylogenies: an approach using the bootstrap. Evolution 39, 783-791.

Hudson, J. A., Morgan, H. W. \& Daniel, R. M. (1986). A numerical classification of some Thermus isolates. J Gen Microbiol 132, 531-540.

Jukes, T. H. \& Cantor, C. R. (1969). Evolution of protein molecules. In Mammalian Protein Metabolism, pp. 21-132. Edited by H. N. Munro. New York: Academic Press.

Logan, N. A., Berge, O., Bishop, A. H., Busse, H.-J., De Vos, P., Fritze, D., Heyndrickx, M., Kämpfer, P., Rabinovitch, L. \& other authors (2009). Proposed minimal standards for describing new taxa of aerobic, endospore-forming bacteria. Int J Syst Evol Microbiol 59, 2114-2121.

Ludwig, W., Strunk, O., Westram, R., Richter, L., Meier, H., Yadhukumar, Buchner, A., Lai, T., Steppi, S. \& other authors (2004). ARB: a software environment for sequence data. Nucleic Acids Res 32, 1363-1371.

Mesbah, M., Premachandran, U. \& Whitman, W. (1989). Precise measurement of the $\mathrm{G}+\mathrm{C}$ content of deoxyribonucleic acid by high performance liquid chromatography. Int J Syst Bacteriol 39, 159-167.

Rainey, F. A., Ward-Rainey, N., Kroppenstedt, R. M. \& Stackebrandt, E. (1996). The genus Nocardiopsis represents a phylogenetically coherent taxon and a distinct actinomycete lineage: proposal of Nocardiopsaceae fam. nov. Int J Syst Bacteriol 46, 1088-1092.

Saitou, N. \& Nei, M. (1987). The neighbor-joining method: a new method for reconstructing phylogenetic trees. Mol Biol Evol 4, 406-425.

Schleifer, K. H. (1985). Analysis of the chemical composition and primary structure of murein. Methods Microbiol 18, 123-156. 
Smibert, R. M. \& Krieg, N. R. (1981). General characterization. In Manual of Methods for General Bacteriology, pp. 411-414. Edited by P. Gerhardt, R. G. E. Murray, R. N. Costilow, E. W. Nester, W. A. Wood, N. R. Krieg \& G. B. Phillips. Washington, DC: American Society for Microbiology.

Steele, T. W., Lanser, J. \& Sangster, N. (1990). Isolation of Legionella longbeachae serogroup 1 from potting mixes. Appl Environ Microbiol 56, 49-53.

Tiago, I., Chung, A. P. \& Veríssimo, A. (2004). Bacterial diversity in a nonsaline alkaline environment: heterotrophic aerobic populations. Appl Environ Microbiol 70, 7378-7387.
Yoon, J.-H., Weiss, N., Lee, K.-C., Lee, I.-S., Kang, K. H. \& Park, Y.-H. (2001). Jeotgalibacillus alimentarius gen. nov., sp. nov., a novel bacterium isolated from jeotgal with L-lysine in the cell wall, and reclassification of Bacillus marinus Rüger 1983 as Marinibacillus marinus gen. nov., comb. nov. Int J Syst Evol Microbiol 51, 2087-2093.

Yoon, J.-H., Kang, S.-J., Schumann, P. \& Oh, T.-K. (2010). Jeotgalibacillus salarius sp. nov., isolated from a marine saltern, and reclassification of Marinibacillus marinus and Marinibacillus campisalis as Jeotgalibacillus marinus comb. nov. and Jeotgalibacillus campisalis comb. nov., respectively. Int J Syst Evol Microbiol 60, 15-20. 